Finn Frandsen* \& Winni Johansen*

\title{
The Apology of a Sports Icon: Crisis Communication and Apologetic Ethics
}

\begin{abstract}
Apologies are often used strategically in the crisis communication of an individual or an organization. In March 2006, highly celebrated Danish handball coach, Anja Andersen, withdrew her team in the midst of a match watched by a large number of spectators. The incident created immediate consternation, not only among sports officials, but also in the Danish media, representing a serious threat to the image of both the handball coach and her club. The following day, Anja Andersen apologized in public on television, but without evoking unambiguous forgiveness from all parties involved. This article examines how and why the Danish handball coach did not succeed in performing a correct and effective apology applying and testing Keith Michael Hearit's theory of crisis management by apology, and especially his communication ethic or apologetic ethics which deals with crisis communication after an (alleged) wrongdoing.
\end{abstract}

\section{Introduction}

On March 5, 2006, Danish female handball team Slagelse plays an important match against their rivals from Aalborg DH. The match takes place in Gigantium, a multi-hall in Aalborg in the northern part of Denmark, and is broadcast by television. Almost 5,000 spectators are watching the match inside the hall, while several hundred thousand television viewers are following the combat at home in front of their television screens. Handball is among the most popular sports in Denmark. At the end of the first half, the coach of the handball team from Slagelse, Anja Andersen, an internationally renowned sports icon within female handball, withdraws her team from the match protesting against a series of negative decisions made by the two referees. The players go down to

\footnotetext{
* Finn Frandsen \& Winni Johansen ASB Centre for Business Communication Aarhus School of Business, University of Aarhus Fuglesangs Allé 4 
the locker room, but return shortly after resuming the match which is finally won by Aalborg DH. The following day, on March 6, the incident attracts a good deal of attention and comments from both sports officials and the Danish media. In the evening, Anja Andersen gives a press conference seconded by the chief communication officer of the club, Henrik Madsen. During this press conference, the Danish handball coach apologizes explicitly for the course of events and her wrongdoing, but the media coverage of the next day does not seem to agree about the sincerity of her apology. What went wrong?

The aim of this article is to examine how and why Anja Andersen did not succeed in offering an apology that could produce immediate forgiveness from all parties hereby stopping the negative media coverage caused by the unfortunate handball match. Apologies are an integral part on many of the lists of crisis response strategies established by crisis communication researchers during the last 10 to 15 years (cf. Benoit 1995, Coombs 1999). However, so far the attention attracted among researchers by this verbal strategy in the crisis communication of individuals or organizations has been scarce. North American rhetorician and crisis communication researcher Keith Michael Hearit is one of very few scholars who has devoted scientific interest to the study of apologies as a crisis response strategy (cf. Hearit 1994, 1995, 2001, 2006). In this article, we shall apply and test his theory of crisis management by apology, and especially his communication ethic or apologetic ethics elaborated for how an individual or an organization should communicate (apologize) after an (alleged) wrongdoing, in order to find an answer to the question: Why did the apology of Anja Andersen not succeed in producing forgiveness?

\section{The Apology: Definition and Typology}

Before we take a closer look at the apology used as a response strategy within crisis communication, we shall shortly concentrate on how to define and typologize an apology. In his book Mea Culpa: A Sociology of Apology and Reconciliation (1991), social scientist Nicholas Tavuchis emphazises the essential relational character of the apology. An apology is first and foremost a "speech act" (Tavuchis 1991: 22), that is, a piece of verbal communication, and like all kinds of communication it has a dyadic structure or is the result of an interaction between two 
actors: the offender and the offended (Tavuchis 1991: 46). This dyadic structure or interaction can neither be reduced nor augmented without causing a radical transformation of the very nature of an apology.

Departing from this understanding of the apology as a specific type of social exchange, Tavuchis has established a small typology of apologies based on the number of individuals included in the units of interaction (the offender and the offended). In this way, he makes a distinction between the following "four structural configurations of apology" (Tavuchis 1991: 48):

1) Interpersonal apology from one individual to another, or One to One

2) Apology from an individual to a collectivity, or One to Many

3) Apology from a collectivity to an individual, or Many to One

4) Apology from one collectivity to another, or Many to Many

The apology performed by Danish handball coach Anja Andersen that will be examined in section 5 in this article represents a combination of structural configuration 1 and 3. On one hand, we have a situation where an autonomous person apologizes in front of a large aggregates of individuals; on the other hand, at the same time this person represents an organization, in this case a handball team and a sports club, which suffers from her wrongdoing and where she can no longer speak or act at her own convenience.

\section{The Apology as Image Restoration or Crisis Response Strategy}

Within the field of crisis communication, it is possible to identify at least two important research traditions. ${ }^{1}$ The first tradition can be char-

1 Timothy Coombs, too, divides the crisis communication research into two categories that reflect different research interests: form and content. "Form indicates what should be done. For instance, crisis managers are told to respond quickly. Content addresses what is actually said in the messages. For example, crisis managers are urged to express sympathy for crisis victims" (Coombs 2006: 171). However, the two categories established by Coombs do not represent two different research traditions. Actually, the first category is described by Coombs as a category where there is "a general lack of research" and where "the form lessons are born from direct experience with crises or case analysis", whereas the second category is described as "more rigorous than the 
acterized as rhetorical or text-oriented, i.e. the researchers belonging to this tradition first of all are interested in studying how an organization communicates, when its image or reputation is under attack. Or to put it differently, they are focussing on how spokespersons of organizations, from CEOs to corporate communication officers, talk and write when defending the organization they represent. The main representative of this tradition is North American rhetorician William L. Benoit who has developed a theory of crisis communication as image restoration or repair strategy (cf. Benoit 1995, 2004, Brinson \& Benoit 2000 and Johansen \& Frandsen 2007). The second tradition can be characterized as strategic or context-orientered, i.e. the researchers belonging to this tradition first and foremost are interested in describing and explaining how the situation has an influence on and determines the form and the content of the crisis communication: what to say, how to say it, when and where. An important representative of this tradition is North American public relations researcher W. Timothy Coombs who has developed a Situational Crisis Communication Theory (SCCT) (cf. Coombs 1999, 2006 and Johansen \& Frandsen 2007).

Within both of these traditions, apologies are considered as forming an important strategy for the crisis communication of an individual or an organization. Benoit (1995) has established a list consisting of five general image restoration or repair strategies, i.e. five typical ways of defending one self when the image or reputation of an indivual or an organization is under attack due to an undesirable act that produces a crisis. They are the following: 1) denial, 2) evading responsibility, 3) reducing offensiveness, 4) corrective action og 5) mortification. Benoit describes mortification (or apology) in the following way: "The accused may admit responsibility for the wrongful act and ask for forgiveness, engaging in mortification. If we believe the apology is sincere, we may choose to pardon the wrongful act” (Benoit 1995: 79). Coombs (1999) has established a similar list of crisis response strategies, in this case including seven general strategies: 1) attack the accuser, 2) denial, 3) excuse, 4) justification, 5) ingratiation, 6) corrective action og 7) full apology. Coombs describes apology in the following way: "Crisis

form research” (Coombs 2006: 174). In fact, the first category represents the practically oriented consultancy literature, and only the second category represents a research literature in the proper sense of the word. 
manager publically states that the organization takes full responsibility for the crisis and asks for forgiveness for the crisis. Some compensation (e.g., money or aid) may be included with the apology" (Coombs 1999: 123). Although both Benoit and Coombs pay attention to the importance of the apology as a crisis response strategy including this strategy in theirs lists, none of them so far have made empirical in-depth studies of the strategic use of apologies.

\section{Crisis Management by Apology}

North American rhetorician and crisis communication researcher Keith Michael Hearit is one of very few scholars who has carried out detailed studies of the use of apologies as a strategy for the crisis communication of both individuals, organizations, and institutions. ${ }^{2}$ In his book Crisis Management by Apology: Corporate Response to Allegations of Wrongdoing (2006), he has elaborated both a theoretically-oriented model describing and explaining the process of apologizing and a more practically-oriented model consisting of an ideal ethical normative standard - an apologetic ethic - regarding both the manner and the content of performing an apology. In this section, we shall give a short introduction to these two models. In the next section, we shall then apply and test the two models to the Anja Andersen case in order to analyse and especially evaluate how "good" or ethically "correct" her apology was.

\subsection{The Process of Apologizing}

According to Hearit (2006), offering an apology forms part of a longer and rather complicated process consisting of a series of stages. Within a traditional religious, and in Denmark this means Christian, universe, the process would include: transgression, feelings of guilt, apology and

2 Keith Michael Hearit describes his own approach within the crisis communication research as a terminological approach: "Given the terminological nature of crises, crisis management is a form of issue management, in which crisis managers attempt to control the terms used to describe corporate actions" (Hearit 1994: 11). Recently, this approach has developed into what Hearit calls a social constructionist approach to crisis management where crises are defined as "above all communicative creations" (Hearit \& Courtright 2003: 80; see also Hearit \& Courtright 2004). 
forgiveness. Departing from rhetorics and apologia research (Ware \& Linkugel 1973, Kruse 1981, Ryan 1982), Hearit transforms the process into a model in five stages:

1. A sociocultural order is transgressed by an individual, an organization or institution due to a specific act of wrongdoing. By sociocultural order Hearit means a community with laws, norms and values for how the members of the community should think, talk and act. Some of these behaviour controlling elements are of legal nature and managed by the police and the judiciary, while others are of a more ethical kind and rooted in the citizens' idea of "what you are allowed and not allowed to do". A complete merging of the legal and the ethical is far from always the case. An organization may act in a way which remains within existing law, but offends public morality in society. You often see this in cases where an organization is exploiting a so-called "loophole in the law".

2. The individual, organization or institution responsible for the transgression is accused of wrongdoing by the community. Hearit (2006: 81) refers to the rhetorical concept of kategoria (Ryan 1982). ${ }^{3}$

3. As a consequence of the accusation, a social legitimation crisis arises between the offender responsible for the wrongdoing and the community. Hearit (1995) introduces corporate social legitimacy theory (cf. Dowling \& Pfeffer 1975, Epstein 1972, Stillman 1974) in order to give a more detailed description of the genesis of a legitimation crisis. According to this theory, an organization will always be in a state of dependence on their surrounding world, or formulated in another way: an organization can only survive to the extent that it can convince its surrounding world that it acts in the right way. Thus, Hearit defines legitimacy as an organizational resource making it possible for organizations to attract employees (manpower), investors (capital), customers, or political support. There are two criteria that an organization must fulfill in order to achieve and main-

3 Proposing to treat accusation and apology as a speech set, Ryan (1982) defines kategoria in the following way: »The Greek noun kategoria signifies 'an accusation, charge', and the Greek verb kategoreo is defined as 'to speak against, to accuse' " (Ryan 1982: 255). 
tain legitimacy. The first criterion is competence, which means "organizational effectiveness - the ability of a corporation to 'deliver the goods'. A corporation must produce a product or deliver a service that meets with some success in the marketplace; one that does not break even, and hence fails to meet its obligations, understandably loses legitimacy with suppliers, bankers, and customers" (Hearit 1995: 2). The second criterion is community, which means that "a corporation's actions must be ethically defensible; that is, its acts must demonstrate responsibility, create trust, and be legal. A corporation draws from communities raw materials, labor, and oftentimes tax abatements; in return, communities expect it to act, or at least speak, in a responsible way that warrants public acceptance and acquiescence” (Hearit 1995: 3).

4. The individual, organization, or institution responsible for the wrongdoing apologizes for its wrongful actions and asks for forgiveness. Hearit (2006) refers to the rhetorical concept of apologia. ${ }^{4}$

5. If the apology is perceived as correct by the community, the individual, organization or institution in question receives forgiveness, and the sociocultural order is re-established.

\subsection{Apologetic Ethics}

On the basis of the theoretically-oriented or descriptive model presented above, Keith Michael Hearit and his colleague Sandra L. Borden have elaborated a communication ethic or an apologetic ethics. This time, there is question of a more practically-oriented model which puts forward a normative standard for ethically correct crisis communication that deals with "the communication after the (alleged) wrongdoing, rather than the ethics of the alleged wrongdoing itself" (Hearit 2006: 61). Using this model, one is able to evaluate more precisely to what extent the apology of an individual or an organization fulfills the cri-

\footnotetext{
4 Ryan (1982) defines apologia in the following way: »The Greek noun apologia is defined broadly as a 'speech in defense', and the Greek verb apologeomai includes a variety of defenses which were not limited to a defense of character: 'speak in defense, defend oneself, speak in answer to, defend oneself against, defend what has been done'«(Ryan 1982: 255).
} 
teria of an ideal ethical standard and thereby really is or functions like an apology. The two researchers find the foundation of this apologetic ethic in casuistry defined as an ethical understanding which dissociates itself from what Albert Jonsen and Stephen Toulmin in their book The Abuse of Casuistry: A History of Moral Reasoning (1988) call the "tyranny of principles" (Jonsen \& Toulmin 1988: 5).

According to a traditional understanding, ethics is a kind of theoretical science or code of general rules and principles which are exhaustive, that is, they cover all situations - without exceptions. According to casuistry, such a view leads to an oversimplification of moral problems. It is a view bewitched by "the dream of an ethical algorithm - a universal code of procedures capable of providing unique and definitive answers to all our moral questions" (Jonsen \& Toulmin 1988: 5). How attractive this view may be, one quickly runs into difficulties in practice when applying this ethical algorithm to cases from real life.

For instance, what do you do, when there is a conflict between two principles, or when a situation is either ambiguous or marginal? If you knock on the door of your neighbour in order to borrow a couple of chairs because you are going to have visitors that same evening, it goes without saying that the neighbour will expect you to deliver the chairs back the following day or when you no longer need them. Here there is no problem in applying an ethical rule telling that you must give back what you have borrowed from others. But what if this thing you have borrowed is a sporting gun, and not a couple of chairs, and if the neighbour in the meantime suddenly turns aggressive threatening to kill another neighbour? Then the situation immediately becomes more problematic because the rule of giving back what you have borrowed from others is then in conflict with the rule telling that we must not take the lives of others or contribute to such an event. According to casuistry, in these problematic situations you have to go behind the general principles and rules in order to take a closer look at each single case. Principles and rules will never be entirely self-interpreting, or formulated in another way: the solution to a conflict between two principles or rules will never be written into them.

According to casuistry, ethics is not a theoretical science, but what Aristotle named pronesis or practical wisdom departing from the fact that ethical principles and rules will never be exhaustive and that you 
therefore have to include the circumstances of each single case. Casuistry itself consists of a method or procedure whereby first a series of ethical situations are established that according to everybody all may serve as ethical standards or paradigm cases of actions which are either clearly moral (and therefore acceptable) or clearly immoral (and therefore unacceptable). Then, by comparing ethically complex or ambiguous situations with the established standards or paradigm cases it becomes possible to specify degrees of ethical correctness. Or formulated in another way: the uniform picture of the traditional understanding of ethics is replaced by a more balanced perspective closer to reality.

Hearit and Borden apply the method or procedure of casuistry in two steps. First, they establish an ethical standard or paradigm case for both the manner and the content of the communication, when an individual or an organization wants to apologize for its wrongdoing. Then, they add a series of complicating circumstances which justifies that the offender departs from the paradigm case on one or several points "while still retaining the essential character of an apologia” (Hearit 2006: 74).

\subsubsection{Manner of the Communication}

Concerning the manner of the communication, an apology used as a strategy in the crisis communication of an individual or an organization, must live up to the following ideal ethical standard. According to Hearit (2006: 64), an ethical apologia must be:

- Truthful.

- Sincere.

- Voluntary.

- Timely.

- Addresses all stakeholders.

- Is performed in an appropriate context.

An apology must be truthful (which does not mean that it has to tell the truth) implying that it must not leave out important information which if revealed to others - would change the way that they see the wrongful actions carried out by the apologist. Thus, the apologist must not lie or deceive. However, the criterion of truthfulness acknowledges "the propensity of individuals and organizations to "strategically name" their 
wrongdoing", although "the names submitted by apologists must bear some resemblance to reality of 'the facts of the case"' (Hearit 2006: 64). When the Chrysler Corporation in the summer of 1987 was accused of having executives driving around in newly produced cars with the odometer disconnected, that is, cars which later would be sold as "new" cars, this action, that many for certain would label as "cheating", was named "test programme" by Chrysler Corporation Chairman Lee Iacocca (Hearit 1994).

An apology must also be sincere. This has three implications. First, the apologist must demonstrate a good-faith effort to achieve reconciliation. This can be done by carrying out actions where the apologist shows that she really wants to solve the problem, for example by recalling a defect product in order to change or repair it before it is promoted on the market again. Secondly, the apologist must demonstrate her sincerity, not only at the operational level, but also at the communicative level. In other words, the company not only has to recall the product; it must also tell the customers that it will do it. Finally, the apologist must also demonstrate that she really wants to reconcile with all the offended stakeholders and that she is not only addressing journalists trying to escape a negative media coverage. An apology also has to be voluntary, that is, performed without any form of coercion.

The timeliness of an apology has to do with timing, that is, when to perform the apology. It is important that the apology is not performed too soon or too late. If the apology is performed too soon, there will often be doubts about the motives behind, and the apologist risks that the apology is seen as either condescending or based exclusively on self-interest. If the apology is performed too late, the apologist in return risks to be perceived as a repellent actor who is not able to show empathy. Conclusion: not always does "time heal all wounds"; sometimes, it also creates new wounds.

Concerning the last two criteria, an apology must be addressed to all relevant stakeholders, that is, all the stakeholders who directly or indirectly have been offended by the wrongdoing and have suffered from it either physically or mentally (morally). The context wherein the apology will be performed has to be appropriate, that is, accessible for all relevant stakeholders. It can be a specific geographical or physical place or it can be a specific medium such as television. 


\subsubsection{Content of the Communication}

Concerning the manner of the communication, an apology used as a strategy in the crisis communication of an individual or an organization, must live up to the following ideal ethical standard. According to Hearit (2006: 69), an ethical apologia must contain the following features:

- Explicitly acknowledges wrongdoing.

- Fully accepts responsibility.

- Expresses regret.

- Identifies with injured stakeholders.

- Asks for forgiveness.

- Seeks reconciliation with injured stakeholders.

- Fully discloses information related to the offense.

- Provides an explanation that addresses legitimate expectations of the stakeholders.

- Offers to perform an appropriate corrective action.

- Offers appropriate compensation.

The apologist must explicitly acknowledge that she has acted in a wrongful way and she must accept full responsibility for the offense expressing regret for what has been done. This aspect of the apology among other things prevents the organization from pointing out an internal or external scapegoat to whom it may shift the blame.

In relation to injured stakeholders suffering directly or indirectly from the wrongdoing, the apologist must show sympathy or empathy. She must ask for for forgiveness for what has happened and seek reconciliation. If we presume that the relationship to the stakeholders was of a positive nature before the wrongdoing, the reconciliation will be of interest for both parties. The apologist must be open disclosing all information related to the wrongdoing - unless this is inappropriate duediscretion. This aspect prevents the apologist from "releasing pertinent information in a piecemeal fashion just to avoid conflict or embarrassment" (Hearit 2006: 72).

Concerning explanations that address legitimate expectations among stakeholders, this means that the apologist must apologize within a frame that makes sense to all relevant stakeholders. One of the implications of this aspect is that the offense itself together with causes and 
effects of the wrongdoing in question must be discussed. When the Exxon Corporation wanted to apologize for the severe pollution of the Alaska coastline caused by the Valdez oil spill in Prince William Sound on March 24, 1989, the company took out a full-page advertisement in magazines and newspapers to apologize to "the people of Alaska". However, both in this open letter and in the following crisis communication, the Exxon Corporation forgot to address the group of people who had suffered the most from the pollution: the fishermen who made their living by fishing in Prince William Sound (Hearit 1995).

Concerning corrective action, the apologist may express that she has learned her lesson declaring that she will no longer engage in such an action avoiding the circumstances that made the wrongdoing possible. And finally, when it comes to offering an appropriate compensation, this compensation often take the form of a financial settlement, but there exist other possibilities. Hearit (2006: 73) mentions that the Chrysler Corporation did not offer a financial compensation to those whose cars had been "tested" with the odometer disconnected, but offered a free checkup and extended warranties.

\subsubsection{Complicating Circumstances}

According to Hearit (2006: 74), there are at least five complicating circumstances. They are the following:

- Catastrophic financial losses.

- Grave liability concerns.

- A moral learning curve.

- The problem of full disclosure.

- Discretion.

If the individual or organization responsible for the wrongdoing is in a difficult situation that makes a financial compensation impossible, a departure from the ethical standard or the paradigm case is justified according to Hearit and Borden. As the proverb goes: "you cannot get blood out of a stone". However, the apologist may still choose to offer a nonfinancial compensation. Concerning liability, there are categories of wrongdoing where the liability is so great (especially in the United States of America) that the organization will not survive. This situation, too, justifies a departure from the ethical standard or paradigm case. 
The organization may solve the problem by expressing regret for its actions, but without accepting full responsibility.

Although timing, as said before, is very important, a late apology is better than no apology at all. This is often the case when the apologist has gone through what Hearit calls a "moral learning curve" (Hearit 2006: 75): at the beginning of the crisis, the organization denies and disclaims responsibility for the wrongdoing, but later on in the course of events and after careful consideration, it ends with offering an apology.

Concerning the problem of full disclosure, this complicating circumstance is about to what extent the organization qua organization fully knows the extent and character of its wrongdoing. The top management of an organization may easily be uninformed or know less about the wrongdoing than others - at the individual level - inside the organization. In such a situation, it is difficult to be thruthful and to disclose all relevant information. Finally, there is the problem of discretion. Discretion is a complicating circumstance to the extent that the apologist must abstain from performing an apology and from offering compensation in public out of regard for confidence.

\section{Case Study: The Apology of a Sports Icon}

On March 5, 2006, Danish female handball team Slagelse - also known as the "Dream Team" - plays an important match against their rivals from Aalborg DH, another important Danish handball team. The match takes place in Gigantium, a multi-hall in Aalborg in the northern part of Denmark, and is broadcast by television. Almost 5,000 spectators are watching the match inside the monumental hall, while several hundred thousand television viewers are following the combat at home in front of their television screens. At the end of the first half, the two referees of the match, Henrik Mortensen and Claus Gram, give Anja Andersen, internationally renowned sports icon within female handball and now legendary coach of the "Dream Team", a red card for pulling the arm of one of the referees. Protesting against the red card and a series of other negative decisions made by the two referees, she leaves the playing field together with her players. They go down to the locker room, but return shortly after resuming the match with permission from the 
referees. The match is won by Aalborg DH with the score at 40-26. It is Slagelse's first defeat of the season.

After the match, the chief communication officer of Slagelse, Henrik Madsen, declares: »Anja Andersen felt that the referees hit the greatest lower bound for what can be accepted in a top match like this. This is the reason why she made use of a non-traditional method leaving the field together with her players. She wanted to demonstrate that she was in shock over what had happened « (Bech 2006).

The following day, on March 6, the sports sections of the morning papers are filled with articles about the dramatic incident. In Politiken, an important Danish newspaper, the secretary general of the Danish Handball Federation, Hans-Christian Jacobsen, is quoted for his statement of the day before referring to the unfortunate match: »The behaviour of Anja Andersen is a disgrace to the sport and a clear manifestation of her lack of leadership. It is a matter of neglect of the sport to produce such an outrageous situation, and I consider it an aggravating circumstance that the top match was broadcast by television « (Bech 2006). To Jyllands-Posten, another important Danish newspaper, HansChristian Jacobsen declares: "A totally scandalous behaviour which displays her lack of management capabilities. She puts herself before the project, that is, to win a handball match. She is frustrated and acts emotionally. But it damages the reputation of the handball sport very badly « (Skadhede 2006).

In the evening of the same day, Anja Andersen gives a press conference seconded by her chief communication officer, Henrik Madsen. During this press conference broadcast by Danish television, Anja Andersen apologizes for her wrongdoing using the following wording: »I would like to apologize to all persons who are in need of an apology. I regret that it happened. I cannot explain why. I must obviously have been weak bringing myself into such a situation « (the Danish television channel TV2, quoted in Jensen \& Philipsen 2006). At the same time, she announces that she plans to resign as coach for Slagelse's »Dream Team « in 2007.

The reactions of the Danish media are far from identical. One newspaper article says: »Anja Andersen regrets her behaviour in Aalborg last Sunday. Monday evening, guilt-ridden and without excuses, she fully accepted responsibility for the scandal she caused when she with- 
drew her team from the field protesting against the referee's decision « (Jensen \& Philipsen 2006). But, another article in the same newspaper adopts a quite different tone: »There is no need to be mushy just because miss Andersen bends down on her knees on-screen apologizing in front of the whole nation. As Anja Andersen has never had this kind of apology on her repertoire, there is no reason to believe that her mortification is an honest confession « (Christensen 2006). Therefore, the following question almost automatically arises: how good or effective was Anja Andersen's apology considered as a crisis response strategy?

\subsection{Analysis of the process}

In order to answer this question, we will first apply the first of the two models elaborated by Keith Michael Hearit:

1. Anja Andersen and her »Dream Team « transgress a sociocultural order, in this case the laws and rules of the European Handball Federation (EHF) and the Danish Handball Federation (DHF) together with people's ordinary idea of »what you are allowed and not allowed to do « during an event of this kind (a top match between two handball teams).

2. The surrounding world accuses first Anja Andersen and then her club Slagelse for having acted (managed) in a very bad and wrongful way. DHF represented by the secretary general Hans-Christian Jacobsen is not the only source of this accusation; many other parties blame Anja for her behaviour:

- Sports journalists like Frits Andersen of Jyllands-Posten who writes: »The management [of Slagelse] must be held responsible for their disastrous failure in not intervening in order to stop Anja Andersen's solo performance, and a kick out of the turnament would not be considered an unreasonable punishment if female handball sport shall maintain a remnant of trustworthiness and esteem « (Christensen 2007)

- Handball coaches like Christian Dalmose, the coach of Aalborg DH: »It is a disgrace for Danish handball. It is the worst thing we have experienced until now (Skadhede 2006). 
- Sponsors who do not express themselves directly in the media, but according to certain journalists they are »running away from the club «.

3. A legitimation crisis arises. This crisis can be described using the two criteria for achieving and maintaining social legitimacy established by corporate social legitimacy theory. Anja Andersen finds herself in the middle of a crisis because of incompetence (as a professional sports manager) and irresponsibility (in relation to the handball sport itself). The statement made by Hans-Christian Jacobsen on March 6, 2006 gives a fine summary of the problem. First incompetence: »a clear manifestation of her lack of leadership« and »a totally scandalous behaviour which displays her lack of management capabilities «. And then irresponsibility: »She puts herself before the project, that is, to win a handball match«. Within modern sports, it is a firm and stable norm that the individual athlete cannot put herself or himself before the sport.

4. Anja Andersen apologizes.

But what about the fifth and last step in the process of apologizing: the forgiveness and re-establishment of the sociocultural order that the apology performed by Anja Andersen was supposed to produce? Here, apparently something is not working (cf. the statements made by some of the journalists). In order to understand what is wrong, we will now apply the second model elaborated by Hearit (and Borden).

\subsection{How Good or Effective Was Anja Andersen's Apology?}

Let us first take a closer look at the manner of communication. Is her apology as performed at the press conference truthful, sincere, voluntary and timely, and does it address all stakeholders in an appropriate context? If we begin with the last of the two questions, we can observe that her apology is performed at the right time, that it addresses all stakeholders and that it is offered in an appropriate context. The press conference takes place on a Monday, the day after the unfortunate handball match, and this is neither too soon, nor too late. It is a clear sign that Anja Andersen has had time enough for reflection. The press conference takes place in a room inside the club house and is broadcast by 
television in such a way that all parties involved can attend and receive the apology.

If we then continue with the other characteristics on the list, the situation becomes a little more complicated. Is the apology thruthful? Perhaps. Anja Andersen tells us that she cannot explain why she behaved like she did - except from a reference to the fact that apparently she must have been weak. Is the apology sincere and voluntary? No, at least not to a satisfying degree. First of all, it is a surprise to see Anja Andersen offering an apology. All through her career, both as an active handball player and as a coach, she has never been the apologizing type. And there have been enough episodes which support this. Secondly, with her choice of words: "I would like to apologize to all persons who are in need of an apology «, she shifts the focus away from herself as a human being who seeks reconciliation and apologizes from the very bottom of her heart to "all persons who are in need of an apology «. She clearly expresses detachment in her way of communicating with her stakeholders. One may ask if the apology is in fact not a result af the strategic spin of chief communication officer Henrik Madsen? If so, the idea is good, but the performance is bad.

Let us then take a look at the content of the communication. At the press conference, Anja Andersen does not explicitly accept full responsibility, but she expresses regret thereby acknowledging that she has acted in a wrongful way. The same regret is expressed later on in the course of events. After Anja Andersen has been sentenced to a quarantine because of her wrongdoing, Slagelse Handball Club sues the Danish Handball Federation (DHF) claiming that the punishment received by the coach is too far-reaching. However, the law-suit ends with a compromise at the city court in November 2006, and in the document presenting the compromise one reads: »Slagelse FH/DT and Anja Andersen still regret the sequence of events during the match on March 5, 2006, in Aalborg « (»Compromise between Slagelse, Anja A. and DHF «, press release from the website of the Danish Handball Federation, retrieved on November 15, 2006).

Concerning solidarity, forgiveness and reconciliation, Anja Andersen's apology does not show sign of any of these. This also goes for explanations addressing legitimate expectations of the stakeholders. »I cannot explain why «, Anja Andersen says. She does not offer to 
perform an appropriate corrective action neither, like saying that in future she intends to behave differently during handball matches. In return, her announcement at the press conference that she will resign as coach for Slagelse Handball Club in 2007 can be viewed as a kind of compensation.

Are there complicating circumstances that justify that Anja Andersen departs from the ideal ethical standard or paradigm case of a good and effective apology? This does not seem to be the case. There are neither catastrophic financial losses nor grave liability concerns that can defend such a departure. The same goes for disclosure and discretion. Anja Andersen was not ignorant of what happened in Gigantium in Aalborg, and she does not need to be discrete due to certain stakeholder groups either. Nevertheless, it is perhaps possible to see the indication of a moral learning curve starting with Henrik Madsen's original statement about the "use of a non-traditional method « immediately after the match in Aalborg and ending with the press conference where Anja Andersen expresses her regrets concerning the incident.

What is then the final evaluation of the apology performed by Anja Andersen if we apply the communication ethic or apologetic ethics elaborated by Hearit and Borden? There is no doubt that the Danish handball coach has in fact expressed her regrets or offered an apology; all the media have noticed this. But there seems to be a disagreement about the sincerity of the apology. Here, it is evident that Anja Andersen could have improved her performance. She could have expressed her apology in a more unambiguous and explicit way, just as she could have focused more on her stakeholders. This is the reason why the media, and with them presumably also a large number of stakeholders, do not agree as much as they could or should in their answer to the question: was the apology performed by Anja Andersen a good and effective apology?

\section{Concluding Remarks}

The various studies of the apology as a crisis response strategy carried out by Keith Michael Hearit form an important and valuable contribution to our knowledge about crises, crisis management and especially crisis communication. His two models, both the theoretically-oriented or descriptive model and the practically-oriented or normative model, will be of great use to individuals and organizations finding themselves 
in a situation where it is suitable to give an apology. The ethical standard or paradigm case for both the manner and the content of the crisis communication may serve as a kind of guideline telling us how to perform a »real« apology.

However, this does not mean that all problems are solved when it comes to apologizing. With globalization, including the role of the media and the new information and commmunication technology, individuals and organizations will to a larger degree face crisis situations where the sociocultural order transgressed by an offender is no longer that evident or common for all parties involved, that is, situations where there are big, maybe even unbridgeable, differences between the laws, norms and values referred to by the social actors when they identify an action as being wrongful and therefore calling for an apology on behalf of the offender.

In the example of Anja Andersen, Slagelse, EHF, DHF, the media and the many Danes passionate about handball that we have examined in this article, there seems to be a certain consensus about »what you are allowed and not allowed to do«. Thus, the sociocultural order is rather evident and common for all parties involved. But if we go to relations across geographical, political and religious borders, lets say between Denmark and the Muslim world (like in the Cartoon Affair), then the sociocultural order or set of orders at once is transformed into a much more complicated entity. And then it also becomes much more complicated to give a »real« apology.

\section{References}

Beck, R. 2006, March 6: Håndbolddirektør: Anja Andersen er en skændsel. Politiken.

Benoit, W.L. 1995: Accounts, Excuses, and Apologies: A Theory of Image Restoration Strategies. New York: State University of New York Press.

Benoit, W.L. 2004: Image Restoration Discourse and Crisis Communication. In D.P. Millar \& R.L. Heath (eds.). Responding to Crisis: A Rhetorical Approach to Crisis Communication. Mahwah, New Jersey: Lawrence Erlbaum. 263-280.

Christensen, F. 2006, March 7: Slagelse må drages til ansvar. Jyllands-Posten.

Coombs, W.T. 1999: Ongoing Crisis Communication: Planning, Managing, and Responding. Thousand Oaks: Sage Publications.

Coombs, W.T. 2006: Crisis Management: A Communicative Approach. In C.H. Botan \& V. Hazleton (eds.). Public Relations Theory II. Mahwah, New Jersey: Lawrence Erlbaum. 
Dowling, J. \& Pfeffer, J. 1975: Organizational Legitimacy: Social Values and Organizational Behavior. Pacific Sociological Review 18.

Epstein, E.M. 1972: The Historical Enigma of Corporate Legitimacy. California Law Review 60. 1701-1717.

Hearit, K.M. 1994: Apologies and Public Relations Crises at Chrysler, Toshiba, and Volvo. Public Relations Review 20. 113-125.

Hearit, K.M. 1995: "Mistakes Were Made”: Organizations, Apologia, and Crises of Social Legitimacy. Communication Studies 46. 1-17.

Hearit, K.M. 2001: Corporate Apologia: When an Organization Speaks in Defense of Itself. In R.L. Heath (ed.). Handbook of Public Relations. Thousand Oaks: Sage Publications. 501-511.

Hearit, K.M. 2006: Crisis Management by Apology: Corporate Response to Allegations of Wrongdoing. Mahwah, New Jersey: Lawrence Erlbaum.

Hearit, K.M. \& Courtright, J.L. 2003: A Social Constructionist Approach to Crisis Management: Allegations of Sudden Acceleration in the Audi 5000. Communication Studies 54(1). 79-95.

Hearit, K.M. \& Courtright, J.L. 2004: A Symbolic Approach to Crisis Management: Sear's Defense of Its Auto Repair Policies. In D.P. Millar \& R.L. Heath (eds.) Responding to Crisis: A Rhetorical Approach to Crisis Communication. Mahwah, New Jersey: Lawrence Erlbaum. 201-212.

Jensen, J.B. \& Philipsen, D. 2006, March 7: Anja A.: Undskyld. Jyllands-Posten.

Johansen, W. \& Frandsen, F. 2007: Krisekommunikation: Når virksomhedens image og omdømme er truet. Copenhagen: Samfundslitteratur.

Jonsen, A.R. \& Toulmin, S. 1988: The Abuse of Casuistry: A History of Moral Reasoning. Berkeley: University of California Press.

Kruse, N.W. 1981: The Scope of Apologetic Discourse: Establishing Generic Parameters. Southern Speech Communication Journal 46. 278-291.

Ryan, H.R. 1982: Kategoria and Apologia: On Their Rhetorical Criticism as a Speech set. Quarterly Journal of Speech 68. 254-261.

Skadhede, J. 2006, March 6: Slagelse udvandrede. Jyllands-Posten.

Stilman, P.G. 1974: The Concept of Legitimacy. Polity 7. 32-56.

Tavuchis, N. 1991: Mea Culpa: A Sociology of Apology and Reconciliation. Stanford: Stanford University Press.

Ware, B.L. \& Linkugel, W.A. 1973: The Spoke in Defense of Themselves: On the Generic Criticism of Apologia. Quarterly Journal of Speech 59. 273-283. 